\title{
TOTAL FLAVONOID, ALKALOID AND TANNIN ON LEAVES AND STEMS OF ABELMOSCHUS MANIHOT L. MEDIK FROM PALU OF CENTRAL SULAWESI
}

\author{
Viani Anggi \\ College of Pharmaceutical Sciences Pelita Mas Palu, Central Sulawesi 94111 , Indonesia
}

email: viani.anggi@gmail.com

\begin{abstract}
Introduction: Abelmoschus Manihot (L.) Medik are herbal medicinal plants, which a rich source compounds of bioactive phytochemical nutrients both on the leaves and stems. Objective: The purpose of the study is analyze the total flavonoid, alkaloid and tannin equivalent on leaves and stems of Abelmoschus Manihot (L.) Medik extracts From Palu of central Sulawesi, was performed on Leaf and stems Extract (Ethanol). Methods: The present study is Analyze of total flavonoid equivalent quercetin, Analyze of total tannin equivalent tannic acid and Analyze of total Alkaloid equivalent quinine on leaves and stems of Abelmoschus Manihot (L.) Medik extracts was performed for Leaf and stems Extract (Ethanol). Results: The results potentially of total activity of flavonoid, alkaloid and tannin equivalent on leaves of Abelmoschus Manihot (L.) Medik is 2,39 \%, 0,09 \% and 63,60 \% and the activity total of flavonoid, alkaloid and tannin equivalent on stems in Abelmoschus Manihot (L.) Medik is 0,46\%, $0,04 \%$ and $12,45 \%$. Conclusion: The present study has Potential to further research with the extraction and isolated a chemichal compound of flavonoid, alkaloid and tannin from Abelmoschus Manihot (L.) Medik with proper standardization methods.
\end{abstract}

Keywords: Abelmoschus Manihot (L.) Medik, Total Flavonoid, Alkaloid, Tannin. 


\section{INTRODUCTION}

Abelmoschus Manihot (L.) Medik are herbal plants with rapid growth, where these plants can only be found in areas with tropical climates, especially in Africa and Asia. The community of Palu in Central Sulawesi knows as a gedi plants, where the gedi plant have with 2 types of gedi, which namely red gedi and green gedi. Gedi plants in particular have long been known and used by the people in central sulawesi as a raw materials for vegetables. For the type of red gedi plant species, traditionally used for the treatment disease. The red gedi plant has a characteristic with a green of leaves and it's streaked with red stems. In Pharmacological studies, where the Abelmoschus Manihot (L.) Medik ethanol extract have the highest significant analgesic effect activity, was observed only by $400 \mathrm{mg} / \mathrm{Kg}$ dose as compared standard of drug and the flowers also reported to be used in tooth'. The Abelmoschus Manihot (L.) Medik also have the significant antiinflamatory effect, where the dose $100,200,400$ $\mathrm{mg} / \mathrm{Kg}$ body weight ${ }^{2}$. Reported isolated compounds of Abelmoschus Manihot (L.) Medik have responsible as a traditional medicine for the similar biological activity and the chemical composition ${ }^{3}$. The scavenging activity of Abelmoschus Manihot (L.) Medik using 1,1-diphenyl-2picryl hydrazil have $I_{50}$ highest values obtained for $\mathrm{N}$-Hexane extract 35,83 $\mathrm{\mu g} / \mathrm{mL}$ and potency as a radical scavenging $\left(\mathrm{IC}_{50}<50 \mu \mathrm{g} / \mathrm{mL}\right)^{4}$. The study of phytochemistry and pharmacology Abelmoschus Manihot (L.) Medik, where the Abelmoschus Manihot (L.) Medik contains saponin, alkaloids, steroids, flavonoids and triterpenoids 5 . The present study is Analyze of total flavonoid equivalent quercetin, Analyze of total tannin equivalent tannic acid and Analyze of total Alkaloid equivalent quinine on leaves and stems of Abelmoschus Manihot (L.) Medik extracts was performed for Leaf and stems Extract (Ethanol).

\section{MATERIALS AND METHODS Materials}

Fresh leaves and stems of Abelmoschus Manihot (L.) Medik. was collected from Palu in Central Sulawesi, of Local Health Herbal traditional, herbarium. Leaves Abelmoschus Manihot (L.) Medik were cleaned and dried at room temperature for a period of 15 days under room. Finely leaf Abelmoschus Manihot (L.) Medik were weighed and extracted using maceration apparatus by solvents ethanol Tools

Specthrophotometry UV-Vis and glass tools used in the chemical laboratory analysis.

\section{Method}

The study is analyze total of flavonoid, alkaloid and tannin equivalent on leaves and stems of Abelmoschus Manihot (L.) Medik extracts From Palu of central Sulawesi, was performed Extract (Ethanol).

\section{Preparation of test solution}

For study the total activity of flavonoid, alkaloid and tannin equivalent on leaves and stems of Abelmoschus Manihot (L.) Medik extracts From Palu of central Sulawesi were prepared from this for carrying out total equiavelent studies where flavonoid, Alkaloid and Tannin in leaves and stems of Abelmoschus Manihot (L.) Medik extracts . 
The first Make a standard curve and considering the standard quercetin 10.0 mg standard solution add $0.3 \mathrm{ml}$ of $5 \%$ sodium nitrite. After 5 minutes add $0.6 \mathrm{ml}$ of $10 \%$ aluminum chloride, wait 5 minutes, add $2 \mathrm{ml}$ of $1 \mathrm{M}$ sodium hydroxide. Add it with distilled water up to $10 \mathrm{ml}$ with a pumpkin measure. Then move it into the cuvette and read of absorption at a wavelength of $510 \mathrm{~nm}$ and than Determination of total flavonoid test Carefully weigh $100 \mathrm{mg}$ of the test sample, put it in a $10 \mathrm{ml}$ test tube. Add 0.3 $\mathrm{ml}$ of $5 \%$ sodium nitrite. After 5 minutes add $0.6 \mathrm{ml}$ of aluminum chloride $10 \%$, wait 5 minutes, add $2 \mathrm{ml}$ of sodium hydroxide $1 \mathrm{M}$. Add it with distilled water up to $25 \mathrm{ml}$ with pumpkin measuring and dilute as needed. Move it into cuvettes, read of absorption at a wavelength of $510 \mathrm{~nm}^{6}$.

\section{Analysis of Total activity Tannin}

Make a standard curve and than Considering carefully the standard solution of Tannic acid, then add $0.1 \mathrm{ml}$ of folin Ciocalteu reagent and vortex, then waiting for about 5 minutes, then add with $2 \mathrm{ml}$ of sodium Carbonat $20 \%$ and then waiting for about 5 minutes then add with aquadest of $10 \mathrm{ml}$. Then make a stock solution, pipette the standard solution $2 \mathrm{ml}$ and add up to $10 \mathrm{ml}$ with aquadest and dilute according to the standard curve concentration. Then the fixed absorbance of absorption was read at a wavelength of $760 \mathrm{~nm}$ after incubation for 30 minutes at room temperature where the standard weight of tanic acid was $0.0100 \mathrm{~g}$. Then made standard 1 1,563 ppm, Standard 23,125 ppm, standard $36,250 \mathrm{ppm}$, standard 4 $12,5 \mathrm{ppm}$, standard $525 \mathrm{ppm}$, standard 6 50 ppm, standard 7100 ppm, standard 8 200 ppm and standard 9400 ppm. To
Determination of total Tannic Acid with 50 $\mathrm{mg}$ extract and $10 \mathrm{ml}$ of chloroform then strain and vaporize the chloroform and add $1 \mathrm{ml}$ of sample solution to volume 10 $\mathrm{ml}$ then take $1 \mathrm{ml}$ of sample solution and add $0.1 \mathrm{ml}$ of Ciocalteu folin reagent and vortex wait for about 5 the next minute add $2 \mathrm{ml}$ of sodium carbonat $20 \%$ and vortex again wait until 5 minutes, then add it with aquadest to a volume of 10 $\mathrm{ml}$. Then the absorbance of absorption is read at a wavelength of $760 \mathrm{~nm}$ after incubation for 30 minutes at room temperature?.

\section{Analysis of Total activity Alkaloid}

Make a standard curve, where considering carefully the Quinine standard $10 \mathrm{mg}$, then add $5 \mathrm{ml}$ of $2 \mathrm{~N} \mathrm{HCl}$ then shake and filter, wash the solution with $10 \mathrm{ml}$ of chloroform 3 times in the separating funnel and then the chloroform phase where the neutralize with the solution with $0.1 \mathrm{~N} \mathrm{NaOH}$ then add $5 \mathrm{ml}$ of BCG solution and $5 \mathrm{ml}$ of phosphate Buffer, Extraction of solution with $5 \mathrm{ml}$ of chloroform with magnetic stirrer with a speed of $500 \mathrm{rpm}$ for 15 minutes, extraction with chloroform and then collect chloroform phase and evaporate with Nitrogen Gas, and add chloroform to volume of $5 \mathrm{ml}$ and then read of absorption are carried out at a wavelength of $470 \mathrm{~nm}$. To Determination of the total alkaloid test Weigh the sample $\pm 100 \mathrm{mg}$ and add $5 \mathrm{ml} 2 \mathrm{~N} \mathrm{HCl}$ then shake and filter. Next wash the solution with $10 \mathrm{ml}$ of chloroform 3 times in a separating funnel and then dispose of the chloroform phase and neutralize the solution with add $0.1 \mathrm{~N} \mathrm{NaOH}$ then add 5 $\mathrm{ml}$ of BCG solution and $5 \mathrm{ml}$ of phosphate buffer, extract the solution with $5 \mathrm{ml}$ chloroform, stir with a magnetic stirer with a speed of $500 \mathrm{rpm}$ for 15 minutes, 
repeating extraction with chloroform 2 times and then collect chloroform and evaporate phase with Nitrogen Gas and add it with chloroform to a volume of $5 \mathrm{ml}$ and then read of absorption are carried out at a wavelength of $470 \mathrm{~nm}^{8}$.

\section{RESULTS AND DISCUSSION}

Table 1. Total Flavonoid, Alkaloid and Tannin equivalent on Leaves of Abelmoschus manihot L. Medik

\begin{tabular}{|l|l|l|l|}
\hline Test Parameters & $\begin{array}{l}\text { Result } \\
\mathrm{s}\end{array}$ & $\begin{array}{l}\text { Uni } \\
\mathrm{t}\end{array}$ & Method \\
\hline $\begin{array}{l}\text { Total Flavonoid } \\
\text { equivalent } \\
\text { Quercetin }\end{array}$ & 2,39 & $\%$ & $\begin{array}{l}\text { Spechtrofotometry } \\
\text { Uv-Vis }\end{array}$ \\
\hline $\begin{array}{l}\text { Total Alkaloid } \\
\text { equivalent Quinine }\end{array}$ & 0,09 & $\%$ & $\begin{array}{l}\text { Spechtrofotometry } \\
\text { Uv-Vis }\end{array}$ \\
\hline $\begin{array}{l}\text { Total Tannin } \\
\text { equivalent Tannic } \\
\text { Acid }\end{array}$ & 63,60 & $\%$ & $\begin{array}{l}\text { Spechtrofotometry } \\
\text { Uv-Vis }\end{array}$ \\
\hline
\end{tabular}

Table 2. Total Flavonoid, Alkaloid and Tannin equivalent on Stems of Abelmoschus manihot L. Medik

\begin{tabular}{|l|l|l|l|}
\hline Test Parameters & $\begin{array}{l}\text { Result } \\
\mathrm{s}\end{array}$ & $\begin{array}{l}\text { Uni } \\
\mathrm{t}\end{array}$ & Method \\
\hline $\begin{array}{l}\text { Total Flavonoid } \\
\text { equivalent } \\
\text { Quercetin }\end{array}$ & 0,46 & $\%$ & $\begin{array}{l}\text { Spechtrofotometry } \\
\text { Uv-Vis }\end{array}$ \\
\hline $\begin{array}{l}\text { Total Alkaloid } \\
\text { equivalent Quinine }\end{array}$ & 0,04 & $\%$ & $\begin{array}{l}\text { Spechtrofotometry } \\
\text { Uv-Vis }\end{array}$ \\
\hline $\begin{array}{l}\text { Total Tannin } \\
\text { equivalent Tannic } \\
\text { Acid }\end{array}$ & 12,45 & $\%$ & $\begin{array}{l}\text { Spechtrofotometry } \\
\text { Uv-Vis }\end{array}$ \\
\hline
\end{tabular}

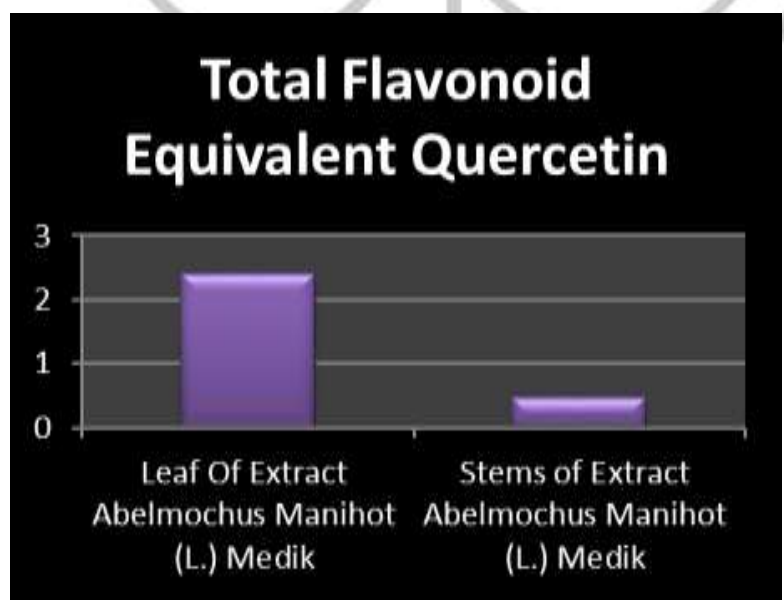

Figure 1. Total Flavonoid equivalent Quercetin on Leaves and Stems of Abelmoschus manihot L. Medik

\section{Total Alkaloid Equivalent Quinine}

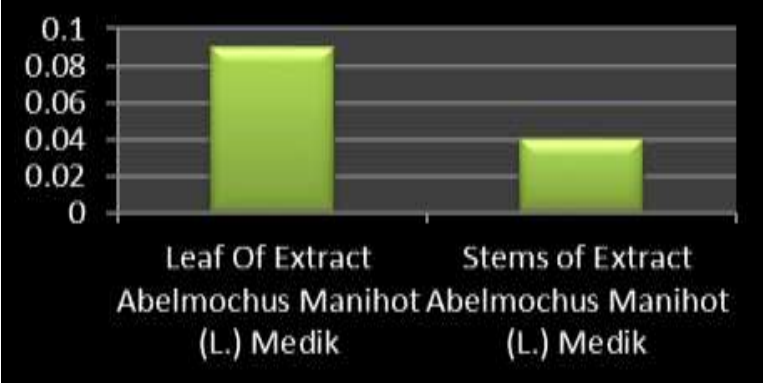

Figure 2. Total Alkaloid equivalent Quinin on Leaves and Stems of Abelmoschus manihot L. Medik

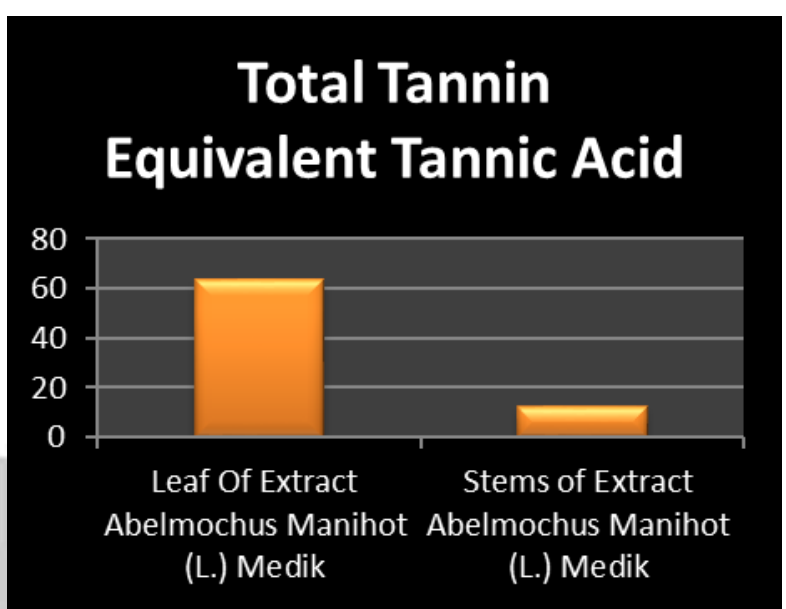

Figure 3. Total Tannin equivalent Tannic Acid on Leaves and Stems of Abelmoschus manihot L. Medik

\section{RESULTS AND DISCUSSION}

In the present study, the total of flavonoid, alkaloid and tannin equivalent on leaves and stems of Abelmoschus Manihot (L.) Medik extracts From Palu of central Sulawesi. Leaves and stems of Abelmoschus Manihot (L.) Medik were cleaned and dried at room temperature for a period of 15 days under room. The leaf and stems Abelmoschus Manihot (L.) Medik were extracted use maceration by solvents ethanol. The total activity potential of flavonoid equivalent quercetin, alkaloid equivalent quinine and tannin equivalent tannic acid in leaves and stems of Abelmoschus Manihot (L.) Medik is displayed in Tables 1 and 2 and Figure 1,2 and 3. The results potential of total activity of flavonoid equivalent quercetin, alkaloid equivalent 
quinine and tannin equivalent tannic acid in leaves of Abelmoschus Manihot (L.) Medik is $2,39 \%, 0,09 \%$ and $63,60 \%$. The total activity of flavonoid equivalent quercetin, alkaloid equivalent quinine and tannin equivalent tannic acid in stems of Abelmoschus Manihot (L.) Medik is $0,46 \%, 0,04 \%$ and $12,45 \%$. The total of flavonoid equivalent quercetin in leaves and stems of Abelmoschus Manihot (L.) Medik is 2,39\% and 0,46\%, it's extensive natural products in Abelmoschus Manihot (L.) Medik. Flavonoid of Abelmochus Manihot (L.) Medik can be used as an antioxidant to regeneration on vero (normal) cells and to preventing the damage of cells and as a nutritional of Abelmoschus Manihot (L.) Medik with highest total flavonoid, where it's significantly to reduce neurologic deficits, infact area and histologic change in brain tisue?. The content of alkaloid in leaves and stems of Abelmoschus Manihot (L.) Medik is $0,09 \%$ and 0,04\%, alkaloid it's protect the body from parasit attacks, as a regulators of cell growth and to stimulate the regeneration of new cells. Alkaloid of Abelmoschus Manihot (L.) Medik as a source of minerals to maintain the ion balance in the body and alkaloid of Abelmoschus Manihot (L.) Medik where potentially prevented of kidney and liver from alleviated progression of Diabetic Nephropathy 10. The content of tannin in leaves and stems of Abelmoschus Manihot (L.) Medik is $63,60 \%$ and $12,45 \%$. Tannin in Abelmoschus Manihot (L.) Medik as an astringent or chelation to the cell ephithel membrane and the biological activities and therapeutic potentially as a diuretic anti microbial ${ }^{11}$. The medicinal plant on leaf and stems of Abelmoschus Manihot (L.) Medik from Palu in Central sulawesi extracts has a potential to further research with the extraction and isolated a chemichal compound of quercetin, alkaloid and tannin from Abelmoschus Manihot (L.) Medik with proper standardization methods.

\section{CONCLUSION}

The results potential of total activity flavonoid equivalent quercetin, alkaloid equivalent quinine and tannin equivalent tannic acid on leaves of Abelmoschus Manihot (L.) Medik is 2,39 \%, 0,09 \% and $63,60 \%$ and total activity flavonoid equivalent quercetin, alkaloid equivalent quinine and tannin equivalent tannic acid on stems of Abelmoschus Manihot (L.) Medik is $0,46 \%, 0,04 \%$ and $12,45 \%$.

\section{ACKNOWLEDGEMENT}

Thanks to Gadjah Mada University, Research and Development Laboratory.

\section{CONFLICT OF INTEREST}

The authors have no conflict of interest.

\section{REFERENCE}

1.Lin-Lin WU, Xin-bo Yang, Zeng ming Huang, He-zhi LIU GW. In Vivo and In Vitro activity of hyperoside extracted from Abelmoschus manihot (L.) Medik. Acta Pharmacol Sin. 2007;28(1):404-409.

2.Jain P.S. BS. Analgesic activity of Abelmoschus manihot extracts. Int $\mathrm{J}$ Pharmacol. 2010;7(1):505-520.

3.M.M O. Ethnomedicinal, phytochemical and pharmacological profile of genus Abelmoschus.

Phytopharmacology. 2013;4(3):648-663.

\section{Waris $R$, Dewi Pratiwi EA, Najib $A$.} Radical Scavenging Activity of Leaf Extract of Edible Hibiscus (Abelmoschus manihot (L.) Medik) Using 1,1-Diphenyl-2Picryl Hydrazil (DPPH). Int J PharmTech Res. 2016:9(5):343-347. 
5.Todarwal A, Jain P, Bari S. Abelmoschus manihot Linn: ethnobotany, phytochemistry and pharmacology. Asian J Tradit Med. 201 1;6(1):1-7.

6.Marques, G. S., Monteiro, R. P. M., Leao, W. D. F., Lyra, M. A., Peixoto, M. S., Rolim Neto, P. J., ... \& Soares LAL. Evaluation of procedure for spectrophotometric quantification of total flavonoids in leaves of Bauhinia forficata Link. Quim Nova. 2012;35:517-522.

7.Dhull SB, Kaur $P$, Purewal SS. Phytochemical analysis, phenolic compounds, condensed tannin content and antioxidant potential in Marwa (Origanum majorana) seed extracts. Resour Technol. 2016;2(4):168-174. doi:10.1016/j.reffit.2016.09.003

8.Gul R, Jan SU, Faridullah S, Sherani S, Jahan N. Preliminary Phytochemical Screening, Quantitative Analysis of Alkaloids, and Antioxidant Activity of Crude Plant Extracts from Ephedra intermedia Indigenous to Balochistan. Sci World $J$. 2017;2017. doi:10.1155/2017/5873648

9.Luo Y, Cui HX, Jia A, Jia SS, Yuan K. The Protective Effect of the Total Flavonoids of Abelmoschus esculentus L. Flowers on Transient Cerebral Ischemia-Reperfusion Injury Is due to Activation of the Nrf2-ARE Pathway. Oxid Med Cell Longev. 2018;2018:1-11. doi:10.1155/2018/8987173

10.Kim H, Dusabimana $T$, Kim SR, et al. Supplementation of Abelmoschus manihot ameliorates diabetic nephropathy and hepatic steatosis by activating autophagy in mice. Nutrients.2018;10(11):1-16. doi:10.3390/nu10111703

11.Pawar AT, Vyawahare NS. Phytopharmacology of Abelmoschus medik. Int J Green Pharm. 2017;1 1(4):648653. 